insecticide residues have been reported from North America ${ }^{6}$.

In the case of breast muscle analyses by the Nature Conservancy marked differences in residue content were evident between raptorial and fish feeding birds on one hand and herbivores on the other (Fig. 1). A similar contrast was evident in eggs analysed by the Government Chomist and the Department of Agriculture for Scotland, where much higher average residue concentrations were reported in peregrine falcons, great crested grebes and herons than in the herbivorous Canada goose and the omnivorous pheasant and carrion crow. The golden eagle and terns occupied an intermediate position (Table 1).

Table 1. Organic Chlorine Insfotionde Residues in BIRDs' Egas (All results expressed in p.p.m. by weight with respect to total egg contents)

\begin{tabular}{|c|c|c|c|c|c|c|}
\hline Species & $\begin{array}{l}\text { No. } \\
\text { nalysed }\end{array}$ & $\begin{array}{c}\text { Average } \\
p p^{\prime}-\mathrm{DDE}\end{array}$ & $\begin{array}{l}\text { Average } \\
\text { dieldrin }\end{array}$ & $\begin{array}{l}\text { Average } \\
\text { total } \\
\text { residue }\end{array}$ & $\begin{array}{l}\text { Range of } \\
\text { total } \\
\text { residue }\end{array}$ & Analyst \\
\hline $\begin{array}{l}\text { Golden eagle } \\
\text { (Aquila chrysaetos) }\end{array}$ & 10 & $1 \cdot 0$ & $1 \cdot 4$ & $2 \cdot 6$ & $0 \cdot 3-10 \cdot 3$ & DA \\
\hline $\begin{array}{l}\text { Peregrine falcon } \\
\text { (Falco peregrinus) }\end{array}$ & 12 & $12 \cdot 4$ & 0.6 & $14 \cdot 4$ & $3 \cdot 0-36 \cdot 0$ & $\underset{\text { GC }}{\text { DA }}$ \\
\hline $\begin{array}{r}\text { Great crested grebe } \\
\text { (Podiceps cristatus) }\end{array}$ & 8 & $5 \cdot 9$ & 0.4 & $10 \cdot 2$ & $2 \cdot 6-22 \cdot 7$ & $\mathrm{GC}$ \\
\hline $\begin{array}{l}\text { Heron } \\
\text { (A rdea cinerea) }\end{array}$ & 2 & $6 \cdot 7$ & $7 \cdot 8$ & $17 \cdot 8$ & $7 \cdot 9-28 \cdot 0$ & GC \\
\hline $\begin{array}{l}\text { Terns } \\
\text { (Sterna spp.) }\end{array}$ & 5 & $1 \cdot 2$ & 0.3 & $2 \cdot 5$ & $1 \cdot 6-3 \cdot 2$ & $G C$ \\
\hline $\begin{array}{l}\text { Carrion crow } \\
\text { (Corvus corone) }\end{array}$ & 10 & $0 \cdot 19$ & 0.05 & 0.33 & $0.17-0.63$ & DA \\
\hline $\begin{array}{l}\text { Canada goose } \\
\text { (Branta cantensis) }\end{array}$ & 4 & $\begin{array}{l}\text { Present } \\
\text { in all } \\
\text { cases }\end{array}$ & $\begin{array}{l}\text { Present } \\
\text { in all } \\
\text { cases }\end{array}$ & \multicolumn{2}{|c|}{$\begin{array}{l}\text { All residues less } \\
\text { than } 0.03 \text { p.p.m. }\end{array}$} & GC \\
\hline $\begin{array}{l}\text { Pheasant } \\
\text { (Phasianus colchicus) }\end{array}$ & ${ }^{7}$ & 0.03 & 0.05 & $0 \cdot 15$ & $0.05-0.26$ & GC \\
\hline
\end{tabular}

The widespread occurrence of organic chlorine insecticide residues in predatory birds which do not normally have direct access to pesticides is an indication of the persistence of these compounds in living organisms. The residue figures pose two main questions: why there are marked differences between groups of birds with respect to residue concentration in their tissues, and what these figures mean in terms of possible effects on bird populations.

Differences in residue concentration between predators and herbivores could be due to differential contamination of food and/or to physiological dissimilarities. The importance of the latter consideration was demonstrated by Gannon et al. ${ }^{7}$ in their work with dieldrin, where 0.4 p.p.m. in feed over 84 days produced 0.5 p.p.m. and 10.0 p.p.m. in the body fat of lambs and hens respectively.
Figures relating organic chlorine insecticide residues in birds to their direct toxic effect have been obtained for bobwhite quail (Colinus virginianus) and pheasant ${ }^{8}$, house sparrow (Passer domesticus) and American robin (Turdus migratorius $)^{9}$. Levels above $30-40$ p.p.m. $p p^{\prime}$-DDT and 6-20 p.p.m. heptachlor epoxide in quail tissues were shown to be evidence of poisoning .

Apart from the question of direct poisoning, sub-lethal doses of aldrin and dieldrin at levels as low as 1.0 p.p.m. in the feed can cause reduced fertility of eggs and viability of chicks in quail ${ }^{10}$. Organic chlorine residues stored in body fat may be a serious hazard to birds when their food reserves are mobilized during periods of starvation ${ }^{9}$.

No definite conclusions can be drawn from the residues found in wild predatory birds in the absence of appropriate experimental data, but a number of the residue figures for predators (for example, 4-20 p.p.m. of dieldrin in the livers of eight specimens) are comparable with values obtained for poisoned non-predators ${ }^{8}$. As it is unlikely that the effect of sub-lethal doses on reproduction is confined to game birds it would be surprising if the levels of organic chlorine insecticides that have been recorded in certain predatory species were of no significance.

The work described here shows that organic chlorine insecticides or their stable metabolites become widely dispersed and are retained in the bodies of a wide range of birds. Their ability to persist in an active form constitutes a wild-life hazard.

We thank Dr. H. Egan of the Laboratory of the Government Chemist (Department of Scientific and Industrial Research) and Mr. N. C. Morgan of the Department of Agriculture for Scotland and their colleagues for performing many of the analyses referred to in this article, and the Royal Society for the Protection of Birds and other donors for specimens.

${ }^{1}$ Rateliffe, D. A., Bird Study, 10, 56 (1963).

'Lockie, J. D., and Ratcliffe, D. A., British Birds (in the press).

- Goodwin, E. S., Goulden, R., and Reynolds, J. G., Analyst, 86, 697 (1961).

- de Faubert Maunder, M. J., Egan, H., Godly, E. W., Hammond, E. W. Roburn, J., and Thomson, J., Analyst (in the press).

5 Evans, W. H., Analyst, 87, 569 (1962).

- George, J. L., in U.S. Dept. Interior, Field and Wildlife Service, Circ. 167 (1963).

'Gannon, N., Link, R. P., and Decker, G. C., J. Agric. and Food Chem. 7, 826 (1959).

${ }^{8}$ DeWitt, J. B., et al., Trans. Twenty-fifth North Amer. Wildlife Conf. (1960). - Bernard, R. F., Publications Museum, Michigan State Univ., Biolog. Sci.. 2, 155 (1963).

${ }^{10}$ DeWitt, J. B., J, Agric. Food Chem., 4, 863 (1956).

\title{
OBITUARIES
}

\section{Sir Alan Gardiner}

Is the death of Sir Alan Gardiner, which occurred on December 19, 1963, Great Britain and the world at large have lost an outstanding Egyptologist and linguist, and a scholar whose industry in research should serve as a model.

At the time of his death, in his eighty-fifth year, Sir Alan had behind him almost seventy years of publishing, for his début goes as far back as 1893, when as a schoolboy of fourteen he wrote two articles on postage stamps of Baden. His father, a prosperous business man, did not think philately a worth-while subject to pursue and asked his son whether there was not anything more serious in which he was interested. "Yes, Egyptology", replied the young Alan after some reflexion. "Then become an Egyptologist", suggested the father, and Alan did. Only two years later, while still at Charterhouse, he saw his first modest article on the Egyptian king Ammenemes I in print, and a constant trickle of articles followed.

With a first-class degree he went from Oxford to Paris to become a pupil of Maspero, the most brilliant Egyptologist of his time. One year in Paris, however, was enough to show young Alan H. Gardiner that Egyptian grammar and dictionary were not the strongest lines of Maspero, although research and progress depended on these for the understanding of Egyptian texts in which Gardiner was, above all, interested. His father's generosity and forethought were going to assure for him a life free from financial worries and the necessity of taking up a remunerative post. Gardiner therefore went to Berlin, where Prof. Erman had gathered around him a group of younger scholars working on precisely the two branches in which Gardiner's main interest lay, especially on collecting material for an Egyptian dictionary sponsored by German academies. Gardiner became an enthusiastic collaborator, at one time even a sub-editor, in this gigantic enterprise, his two most important contributions being copies of Egyptian texts on papyri in the Leiden and Turin museums. These are written in hieratic script which Egyptians developed by simplifying the pictures of the hieroglyphs so that they could easily be written with brush and ink on paper made of stems of the papyrus water-plant. The experience acquired while working on these difficult texts made Gardiner an undisputed master of hieratic.

Gardiner was only twenty-six when his first book appeared in 1905, its subject being the study of an 
inscription relating to a protracted lawsuit in the time of Rameses II. In the few years which followed, Gardiner edited papyri containing admonitions and prophecies of an Egyptian sage, an account of the adventures of the courtier Sinuhe while a refugee in Palestine and a satirical literary letter addressed by one Egyptian scribe to another.

During a journey to Egypt in 1907, Gardiner's attention was directed to the much-neglected and slowly perishing tombs at Thebes, full of important representations and inscriptions. In three winter sessions, first with A. E. P. Weigall and later alone, he compiled a scientific catalogue of the 252 tombs then known, many of them discovered by himself, and later published several of the most important among them, having co-operated with the skilful draughtsman, de Garis Davies, and his wife. It is due solely to them that these important monuments of Egyptian art have beon made accessible for study in accurate copies.

In 1911 Gardiner moved from Berlin to England and settled in London to pursue his research and publications without much interruption. In 1914, at his instigation, the Journal of Egyptian Archaelogy was founded. He was for many years editor and an important contributor to this periodical. At the same time he was collecting material for his monumental Egyptian Grammar. This appeared first in 1927, and its fourth edition is about to appear posthumously - a striking proof of the popularity of the work which initiates the learner gradually into the subject according to modern methods, constantly offering exercises for translations from Egyptian to English and vice versa. In $1928 \mathrm{Mr}$. Chester Beatty entrusted him with the publication of a new find of important papyri. These appeared in two volumes about the same time as others containing late Egyptian stories and scribes' miscellanies, to be followed by administrative texts, a long fiscal document of Papyrus Wilbour and a collection of Egyptian vocabularies. The last major work, Egypt of the Pharaohs (1961), offers to the reader an account of Egyptian history and civilization as they appear to an Egyptologist as a result of a lifetime's work.

Since 1919 Gardiner had been keenly interested in general linguistics. His main work in this field, The Theory of Speech and Language, did not find unanimous approval; but Gardiner was always convinced that this book was a seed which would bear fruit at some future date. There are signs that in this he was not mistaken.

In 1915, preparing for publication with T. E. Peet the Egyptian inseriptions found by Sir Flinders Petrie at Sinai, Gardiner proposed an interpretation for a few short inscriptions written in erude hieroglyphs, but elearly not Egyptian. According to him, these are written in a hieroglyphic alphabet devised by a Semite of the region inspired by the Egyptian writing. This alphabet is the direct ancestor of all subsequent alphabets, including Greek and our own. This view of Gardiner has now been generally accepted.

J. ČERNÝ

\section{Mr. M. L. Jacks}

M. L. JACKS, who died in his sleep at the age of seventy, on January 24 , was a man who had given his whole life to education. $\mathrm{He}$ belonged to the great generation of Balliol College scholars which flowered immediately before the First World War. He was a fine classical scholar and, in the immediate post-war years, a Fellow and Dean of Wadham, but at the age of twenty-eight he became headmaster of Mill Hill School and the youngest public school headmaster in England. No one who was concerned with education in the 'thirties could ever fail to associate Jacks and Mill Hill, and the work which he did there was the sort of contribution which stands out in the history of any school.

But it was at the Department of Education in Oxford, of which Jacks became director in 1937, that he found his final life work, and it is there that he is best remembered to-day. He had many outside interests, but they centred in that concern for young people as individuals which informed all his work in the education and training of teachers. Perhaps because he was a great individualist himself he was one of the greatest champions of the individual child in the educational process, and he never ceased to remind his students that it was the whole child, body, mind and soul, with whom they were concerned. Whether as chairman of a committee, or lecturer or tutor, he believed in expressing fully his individual point of view and encouraging others to express theirs. Where he was, himself, in authority he had a great gift for stimulating this kind of open discussion and then finding an agreed solution which was acceptable to everybody: where he found his own hopes and ideals thwarted he was a model of patience and courtesy. It was this patient, persistent and completely selfless devotion to a cause in which he profoundly believed that enabled him, by almost imperceptible stages, to transform the position of education as a serious and acceptable study in the University. Those who have entered into his inheritance know best how rich that inheritance was.

The titles of his books, God in Education, Total Education and The Education of Good Men, express a consistent philosophy which he expounded in his lectures and exemplified in his conversation with great lucidity and a constant sense of humour. His jokes and his laughter will be remembered in Oxford as will the warmth of his personality, which was only half concealed by a surface austerity. With the foundation of the Institute of Education at Oxford in 1951 his great qualities as a lecturer became known to a much wider circle of teachers, and even after his retirement he kept up his contacts with the many schools of which he was a governor, and was always ready to meet and talk with teachers or students of education.

Both Jacks and his wife were great gardeners and amateur horticulturists, so that his retirement left them with another abiding interest. Two occasions will probably recur to the minds of those who knew him best here: the final gathering in his gardens in Surrey on the occesion of his retirement and a reunion at the Department of Education a few weeks before his death at which those who had served with him nearly thirty years ago heard him speak with all the grace and wit of his youth.

\section{A. D. C. Peterson}

\section{Dr. J. W. Broughton, M.B.E.}

Dr. James W. Broughton died suddenly at his home in Ottawa, on January 21. He was born in Grimsby, England, in 1906, and went to Canada with his parents at an early age. His education in Alberta led to his graduating in 1932 with first-class honours in chemistry from the University of Alberta. He took his master's degree the next year. After a period with Imperial Oil, Ltd., in Calgary, Dr. Broughton returned to studies at MeGill University where he received his Ph.D. in 1937. He then joined the National Research Council, taking charge of the Fuels and Lubricants Laboratory of the Division of Mechanical Engineering, a position he since held continuously.

Throughout his career, Broughton made a great contribution to the development of laboratory analytical and performance methods for the evaluation of all types of petroleum products during an extremely active period in which there have been continual developments in fuels and lubricants. This work has been performed by the laboratory in collaboration with many other Federal and Provincial Government organizations, industrial labora. tories and the Royal Canadian Navy, Army and Air Force.

Dr. Broughton was widely known not only for his work in national organizations such as the Canadian Govern- 